\title{
Business models, stakeholders and capabilities in coping with societal grand challenges: the case of Japan's convenience stores
}

\section{Hendrik Meyer-Ohle ${ }^{1}$ D}

Received: 29 February 2020 / Revised: 9 February 2021 / Accepted: 20 February 2021 /

Published online: 29 March 2021

(c) Springer Nature Limited 2021

\begin{abstract}
In Japan, convenience store operators have hailed their stores as "social infrastructure." Policy makers have acknowledged this role, striving to involve the private sector in the process of strengthening communities, especially in light of Japan's greatest societal challenge: its rapidly aging population. Convenience store companies have also earned such recognition through their responses to natural disasters. This is, however, somewhat paradoxical, since their just-in-time business model is in principle highly vulnerable to such events. This article introduces the case of the Japanese convenience store to demonstrate how responding to grand societal challenges can-beyond demonstrating corporate social responsibility or striving for legitimacy-become an essential part of corporate business models. It argues that such an approach creates the need for higher-level capabilities and increases the number of involved stakeholders, and concludes that this might throw previously successful business models off balance.
\end{abstract}

Keywords Japan · Convenience stores $\cdot$ Societal grand challenges · Disaster · Aging society

\section{Introduction: "the lights are always on"}

The question of how business and management react to and can contribute to solving "grand societal challenges" has increasingly become the focus of management research (Ferraro et al., 2015; George et al., 2016). Grand challenges are defined as substantial unresolved problems that affect large populations (i.e., those that extend beyond single organizations or communities), have a

Hendrik Meyer-Ohle

meyerohle@nus.edu.sg

https://courses.nus.edu.sg/course/jpsmohc/

1 Department of Japanese Studies, National University of Singapore, Block AS8, \#05-06, 10 Kent Ridge Crescent, Singapore 119260, Singapore 
considerable and mostly negative impact on human life, and do not lend themselves to easy solutions (Ferraro et al., 2015). Grand societal challenges include issues such as poverty reduction, environmental protection, or reducing inequality (George et al., 2016). In Japan, the focus of this article, an aging population and disaster resilience stand out as key issues: the two are also interconnected, insofar as achieving disaster resilience is especially difficult in areas where populations are aging and shrinking, and where the provision of goods and services by public and private actors has become increasingly difficult, even under normal circumstances.

Among retail formats, the convenience store (CVS) is Japan's most dynamic, having grown by the year 2019 to encompass a total of 56,500 stores (METI, 2020a), $90 \%$ of which are controlled by just three dominant corporations. Stores are open 24 hours a day, are typically around 130 square meters in size, and carry an assortment of approximately 3000 articles, most of which are intended for quick consumption (daily delivered food, 36\%; processed food, $27 \%$; non-food, $30 \%$; and services, 7\%). Customers spend about 650 yen per store visit (JFA 2020). Introduced in the early 1970s, and having initially enjoyed popularity mostly among young consumers suddenly able to satisfy immediate needs at any time of the day or night (Larke \& Causton, 2005), CVSs have since become widely recognized, and are marketed not as just another retail store but as an essential part of Japan's social infrastructure. Operators emphasize the role their stores play in supporting society and strengthening community resilience. Lawson-the third largest company in Japan, with a network of about 14,500 stores-states in its 2016 annual report:

Identified today as the fourth component of infrastructure after electricity, gas and water, the convenience store is recognized as an essential presence in every region. The lights are always on at Lawson, a situation with significance for community safety. In the event of a major disaster, we will partner with the local government to serve as a lifeline. (Lawson Inc., 2016, p. 9)

Lawson illustrates its claims with a chart titled "Contribute as Infrastructure to Regional Society," ambitiously identifying a wide variety of roles and tasks its stores might fulfill: serving as a lifeline in times of disaster, or functioning as a crime prevention center; supporting agricultural undertakings, greening activities, and energy conservation and production; offering home delivery services and mobile sales; housing an attached nursing care center; and providing health and childcare support (Lawson Inc., 2016). Yet some of these suggestions immediately invite skepticism. For example, at first sight, it seems logical for Japan's $56,500 \mathrm{CVSs}$, which now often prove to be the shopping option nearest to peoples' workplaces and homes, to play a major role in times of disaster. However, a look at the business model of the CVS shows that outlets have very limited storage space beyond what can be stored on their shelves. Merchandise largely consists of ready-to-eat products that are prepared on demand, and require both refrigeration and several temperature-controlled deliveries each day.

This raises the question of why CVS companies engage with Japan's grand societal challenges at all. Do companies just want to brand themselves as 
responsible citizens (CSR), or has engagement with these challenges become an essential element of their business models? If the latter, what consequences does this have for management?

To answer these questions, this article combines institutional, capability, and stakeholder perspectives. It focuses on a critical incident, the Great Eastern Japan Earthquake of 2011, to establish the capabilities of the business model of the CVS, as well as its limitations, both generally and in times of sudden, unpredictable crisis and shock. After consideration of this case, it outlines how CVSs have become engaged with Japan's demographic crisis, a development that is not a sudden shock but is nonetheless severe in its consequences for society and economy. In discussing both developments, the article demonstrates how making engagement with societal challenges a core element of business models, rather than just mere CSR, necessitates the development of higher-level capabilities in terms of communication, flexibility, and diversity. In addition, the article shows how societal engagement increases the number of stakeholders, which can have a potentially destabilizing effect on the relevant business models.

\section{Societal grand challenges and business engagement}

For Japan, its aging population poses the most significant societal challenge. In $2018,28 \%$ of the population was above 65 years of age, and this figure is expected to reach $35 \%$ by 2040 - a development that is progressing much faster outside of Japan's metropolitan regions. In peripheral Akita Prefecture, the proportion of people above 65 years old has reached $36 \%$ already; more than half of its population will be above 65 years old by 2045 (Cabinet Office, 2019a).

An aging populations has often been listed among grand societal challenges (Chand \& Tung, 2014), but in management studies, it has mainly received attention for its consequences on human resources management (Kulik et al., 2014, 2016). But, although Japan's aging population has led to many labor market issues (e.g., Martine \& Jaussad, 2018; Harada et al., 2019), it has also led to significant challenges with regards to the provision of public and commercial services and goods in local communities, where aging is correlated with shrinking populations (Matanle \& Saito, 2010; Ishihara, 2011). Shops are closing in greater and greater numbers, and municipalities, faced with both lower tax incomes and demands from the central government to become financially independent, struggle to provide services to their citizens (Elis, 2011; Ishiguro, 2014; Kawabata et al., 2010). This development began in Japan's periphery, but has been finding its way to the fringes of metropolitan areas (Capitanio, 2018; Kaido \& Tsuruta, 2012; Yui et al. 2017). A discussion of possible solutions has ensued, and while proposed configurations differ, there seems to be some consensus that any solution will have to involve collaboration between private and public actors, and that the retail sector should play a significant role.

This links to Japan's second grand challenge: natural disasters. Due to its geographic location and topography, Japan is among the nations most vulnerable to natural disasters, such as heavy seasonal rain, typhoons, earthquakes, or even volcanic eruptions. In recent years, Japan has been subject to a series of such disasters, such 
as the earthquakes in Hokkaido (1993), Kobe (1995), Tohoku (2011), and Kyushu (2016), as well as extremely heavy rain fronts and typhoons followed by severe flooding in 2014, 2016, 2018, and 2019 (Cabinet Office, 2019b). These disasters have been especially felt in Japan's peripheral regions, which often have elderly and shrinking populations. In order to improve disaster response and resilience, the Japanese government, prefectures, and municipalities have increasingly been looking at involving the private sector (Cabinet Office, 2017).

Research on business engagement with grand challenges has pointed to the need to look at the motivations, capabilities, and stakeholders involved. While many companies get involved in such challenges only for the purpose of conveying a sense of corporate responsibility and philanthropy, some companies react to these challenges by making changes to their core business models. Hamann et al. (2020) recommend more research on such cases. In their own efforts to analyze the motives and actions of socially engaged companies, they draw upon Bansal and Roth's (2000) model of responsiveness to ecological challenges, which differentiates corporate motivations into competitiveness (responsiveness as a means to increase corporate advantages and, eventually, profitability), legitimation (compliance with rules, norms and expectations), and responsibility (concern with social obligations and values). Hamann et al. (2020), however, find the above categorization inadequate for the purposes of explaining corporate activities that seek to strengthen local resilience. Instead, they explain such activities as performed with the intention of protecting place-specific corporate resources. The authors argue that societal challenges put companies' place-specific resources at risk, and that, because policy makers and the public sector often fail to address these challenges, companies may decide to tackle them by themselves.

Indeed, Japanese CVS companies present their operations as being able to contribute to responses to the gradually developing issues of an aging population and (consequently) declining local populations, as well as providing preparedness and relief in the eventuality of sudden disruptive events, such as Japan's frequent natural disasters. Concerning disaster preparedness and relief, there is a growing discourse that highlights the potential contributions of the private sector (Ballesteros et al., 2017; Ergun et al., 2010, 2013; Horwitz, 2009; Martin \& Williams, 2014; McKnight \& Linnenluecke, 2016, 2019; Stewart et al., 2009). Ballesteros et al. (2017) argue that corporate players have, when compared to the public sector, unique capabilities. Following Teece (2007), they see these in "sens[ing] threats and diagnos[ing] areas of critical need following disaster..., seiz[ing] upon opportunities to respond, and quickly reconfigur[ing] routines and resources to do so effectively" (1683).

Capabilities differ by business model, with some businesses coping better or able to contribute more than others in times of disaster (Tierney, 2006). Individual companies or business models can possess capabilities or characteristics that increase their resilience to crises, or benefit the recovery of their operations. These can be seen as "facilitators." Facilitators can be the result of active planning with crisis in mind, but they might also exist as part of an overall business strategy or business model, and only retrospectively be recognized as having had a positive impact on crisis resilience and recovery. Conversely, some companies or certain business models can possess characteristics that make them especially vulnerable to crisis, or 
especially likely to impede the recovery process; these can be seen as "inhibitors." Of course, it is possible for companies or business models to have strengths in some areas and weaknesses in others.

McKnight and Linnenluecke (2016) link firm-level resilience and community resilience. They use a stakeholder approach to argue that, in preparing and responding to disasters, companies find themselves on a continuum between a firm-centric focus on primary stakeholders (supply chain partners and customers), which aims to restore competitiveness, and a community-centric focus, which prioritizes employees, customers, and community members in need. They see the second approach as advantageous in building goodwill with customers, as well as maintaining relationships with governmental and non-governmental agencies (see also Carden, 2009; Horwitz, 2009; Stewart et al., 2009).

Disaster situations also present opportunities for firms to connect with customers (Liu et al., 2012). In such situations, people may come to first realize their dependence on retailers, and to more fully appreciate those that manage to keep operations running. The availability of retail stores also plays an important role in the mental recovery process of people who judge recovery and return to normality by whether they have been able to resume their lives as consumers (Liu et al., 2012). Consequently, Liu et al. (2012) argue that public actors should help retailers to reopen stores quickly.

Japanese CVSs have been characterized by their operators as contributing to two different grand societal challenges: disasters, which are sudden and require resilience, and an aging population, which requires long-term, sustainable systems for the provision of goods and service. Based on the above review of the literature, this article asks about (a) the motivations of CVS operators in getting involved in grand challenges, (b) their capabilities to do so, and (c) the possible obstacles companies face in making their responses to grand societal challenges a core part of their business models.

This research looks at developments over time in one industry, and asks how the business model in this industry has changed. In doing so, it examines both actual change and the discourse among stakeholders. Relevant findings are drawn from a variety of sources, including newspaper reports, annual reports by companies, reports by policy makers, case studies by Japanese academics, and content from Japan's major industry journals and newspapers. These publications take up with the current developments in the industry, and also enable insights into underlying discourses.

In order to further the discussion of the role of CVSs in Japan's grand societal challenges, the Great Eastern Japan Earthquake of 2011 is introduced as a critical incident. In virtue of its large scale, the earthquake put significant strain on the retail sector. For the CVS, specifically, the earthquake occurred shortly after the industry had publicly declared its operations to be part of social infrastructure in 2009. Operators therefore used the earthquake to demonstrate and reflect on their own capabilities. In the year following the 2011 earthquake, industry publications reported extensively on the disaster and its consequences for retailing, even dedicating special issues to the topic. About 450 pages of coverage from this year were collected and analyzed for major themes. Content included field reports immediately 
after the earthquake, coverage of press conferences, interviews or panel discussions with industry leaders, case studies of single companies, stores, or shopping centers, projections of consumer trends, reports about the responses of manufacturers or logistics providers, expert opinions, and more conceptual and normative articles providing advice on how to improve logistics or risk management. A closer look at the motivations and tone of the reporting on the Great Eastern Japan Earthquake shows that this large scale disaster was not just being reported as a disruptive event. Instead, many writers recognized it as an opportunity for a more general reflection on the state of Japan's retail and distribution sector, and especially on its strengths and weaknesses, as well as its current and future role in society and economy. In addition to publications focusing specifically on the retail sector, Nikkei Telecomthe database of Nikkei Inc., Japan's leading publisher of business newspapers-was systematically searched for information on the involvement of CVSs with both disasters and Japan's aging society ${ }^{1}$.

\section{Evolving business model of convenience stores in Japan}

Since introduced into Japan in the early 1970s, the business model of the CVS has continuously evolved. In the following, this development will be described, focusing on changes in stakeholders, capabilities, and the societal discourse surrounding CVSs (Chart 1).

When CVSs were first introduced, Japan's traditional retail infrastructure was still relatively intact. While in the US, CVSs had developed to complement supermarkets that were either located too far away from people's homes or too large for quick shopping, in Japan most people still had stores selling necessities close to their homes, and used them on a daily basis. Thus, the introduction of CVSs based on the US business model initially met with significant skepticism from potential suppliers, and indeed even within the very companies that introduced the CVS to Japan (SIJ 1992; Koyama, 1993). Japan's CVS companies still succeeded, but only after significantly adapting their business models from those developed in the US, as well as learning how to appeal to a new customer group: adolescents, students, and young singles, who began to demand snacks and beverages for quick consumption at all times of the night and day, nearby or on their routes between homes, places of education, or work (Kawabe, 2013; Larke \& Causton, 2005; Meyer-Ohle, 2003). A significant success factor in the introduction of the CVS was the application of the franchise model. Franchisees were initially mostly small retailers who converted their stores into CVSs, thereby providing the franchise operators with retail experience, shop locations, some acceptance in local communities and, when converting liquor stores, the otherwise difficult to get license to sell alcohol. In addition

\footnotetext{
1 The articles from this newspaper database are referenced only in the text with date and page number: as NKS=Nihon Keizai Shinbun (if not stated otherwise morning (date-e = evening edition) and main edition, otherwise regional edition as stated, e-(electronic) edition, or sokuhō (breaking news) as stated, $N M J=$ Nikkei $M J$ (Marketing Journal), NSS = Nikkei Sangyō Shinbun.
} 


\begin{tabular}{|c|c|c|c|}
\hline \multicolumn{4}{|l|}{ Grand Challenges } \\
\hline Societal Discourse & $\begin{array}{l}\text { New Urban } \\
\text { Lifestyle }\end{array}$ & $\begin{array}{l}\text { Environmental and } \\
\text { societal impact }\end{array}$ & $\begin{array}{l}\text { Communal } \\
\text { Infrastructure }\end{array}$ \\
\hline Business Model & $\begin{array}{l}\text { Fulfilling specific needs } \\
\text { in standardized and } \\
\text { efficient way }\end{array}$ & $\begin{array}{l}\text { Adding services to } \\
\text { attract more people } \\
\text { to store, own } \\
\text { products to } \\
\text { differentiate stores }\end{array}$ & $\begin{array}{l}\text { Addressing broad } \\
\text { needs of local } \\
\text { communities }\end{array}$ \\
\hline \multirow[t]{2}{*}{ Orientation } & Firm-centric & Competitor-centric & Community-centric \\
\hline & 1970 & 2000 & 2010 \\
\hline Stakeholders & $\begin{array}{l}\text { Headquarters } \\
\text { Franchisees } \\
\text { Suppliers }\end{array}$ & $\begin{array}{l}\text { Headquarters } \\
\text { Manufacturers } \\
\text { Service providers } \\
\text { Suppliers } \\
\text { Franchisees }\end{array}$ & $\begin{array}{l}\text { Headquarters } \\
\text { Franchisees } \\
\text { Suppliers } \\
\text { Manufacturers } \\
\quad \text { Employees } \\
\text { Service providers } \\
\text { Central government } \\
\text { Local communities }\end{array}$ \\
\hline Capabilities & $\begin{array}{l}\text { Cost reduction } \\
\text { Standardization } \\
\text { System creation }\end{array}$ & $\begin{array}{l}\text { Differentiation } \\
\text { Business Networking } \\
\text { Brand building }\end{array}$ & $\begin{array}{l}\text { Automation } \\
\text { Diversity } \\
\text { Flexibility } \\
\text { Communication } \\
\text { Local Knowledge } \\
\text { Community Networking }\end{array}$ \\
\hline
\end{tabular}

Note: chart created by the author.

Chart 1 Development of discourses, business model and stakeholders. Chart created by the author

to building close relationships with franchisees, CVS chains invested in developing a procurement and delivery infrastructure, which required significant cooperation from suppliers, who had to be convinced to make frequent small lot deliveries to stores. Here it helped that CVS chains had been established by the then-dominant superstore chains, thus ensuring that CVSs did not need to build relationships from scratch. Striving to make CVSs profitable for franchisees as well as suppliers, CVS headquarters made significant investments and innovations in information systems to help shop owners predict demand, and to help suppliers plan their deliveries (Yahagi, 1994). In the initial period of their development, companies thus displayed a firm-centric orientation. Pursuing an untested business model that required major adjustments, companies paid close attention to the situation of their two main stakeholders, franchisees and suppliers.

In the following growth period, from the 1980s onwards, CVS chains increasingly began to compete with each other, and also recognized first limitations to future growth due to their focus on young and single consumers. To draw more customers and utilize their advanced IT infrastructure, companies gradually introduced new services in collaboration with other businesses, such as the payment of 
utilities charges, event ticket sales, or parcel collection. Later, companies began to differentiate store brands more clearly by developing products exclusive to their stores, often in close collaboration with manufacturers. The latter found such collaborations attractive not only due to the significant sales of convenience stores, but also because of the detailed customer data that CVS companies collected, as well as their young consumer base, both of which allowed for quick market testing. In the 1990s, the convenience store sector also increasingly developed into a competition among three leading companies, Seven Eleven, Lawson, and FamilyMart, especially once Japan's large trading companies bought controlling stakes in FamilyMart and Lawson (Marutschke, 2012; Yahagi, 1994). Working with manufacturers and service providers, the number of involved stakeholders expanded. Having become an established retail format with a significant share of overall retail sales, companies could increase their demands on franchisees and suppliers. This is evidenced by a heightened interest in the potential misuse of their growing power by Japan's Fair Trade Commission. In 1998, it investigated Lawson for the way the company treated suppliers; in 2001, it charged CVS companies with providing deceptive information when recruiting new franchisees; and, in 2009, it warned Seven Eleven about its methods of charging royalties from franchisees (NKS, 17/04/1998:7; NKS, 1/11/2001:38; NKS, 20/02/2009-e:17; Nogimura, 2015).

Apart from its treatment of franchisees and suppliers, the CVS faced criticism for contributing to uniform urban landscapes, selling unhealthy food, promoting eating away from families, offering hangouts for young people, providing easy access to tobacco, liquor, and pornographic magazines, and consuming vast amounts of electricity through continuous air-conditioning, intense refrigeration of products, and around-the-clock opening hours (Shigeru \& Araki, 2008; Nogimura, 2015; Nishida \& Yamamoto, 2015; Ishihara, 2019). Finally, while CVS chains generated significant sales and profits, the franchisee model ensured that this resulted in only low local tax contributions. The significant royalties paid to headquarters are deductible as costs, and the remaining income is accounted for separately, often by relatively lowly taxed individual franchisees (NKS Osaka, 12/3/2007-e:29).

Eventually, the industry decided to frame their store networks as a part of social infrastructure. In May 2009, the industry issued its "Convenience Stores as Social Infrastructure Declaration," promising to engineer CVSs that are friendly to the environment and contribute to the safety and security of communities, as well as to the vitalization of local economies (JFA, 2011). Significantly, although the declaration promised to pursue various new initiatives, it also demanded more cooperation between companies so as to better publicize what was perceived as the existing positive contributions of CVSs.

\section{The 2011 great eastern Japan earthquake}

People became suddenly distressed when the retail functions that had supported people's lives were abruptly disrupted. Retailers, just thinking of business efficiency, had prioritized frequent small lot deliveries, convenience stores 
had reduced stocks to its minimum, in times of emergency logistics stopped and this became a hurdle to sales. (Nishikawa, 2011, p. 74)

On March 11, 2011, a powerful earthquake struck Japan. The epicenter of the earthquake was off the northeastern coast, near Sendai, but it was so strong that it also brought all transport in Tokyo to a standstill. The earthquake triggered a tsunami that flooded large areas along the coast, which together killed about 16,000 people, with more than 2500 people remaining unaccounted for. A meltdown of reactors at the Fukushima nuclear power plant soon followed, eventually leading to the mass evacuation of people from the surrounding areas.

The earthquake caused significant damage and disruptions in a large area extending across eastern Japan. It destroyed or damaged people's homes, transport infrastructure, and businesses. In the CVS sector, only 320 of the 918 stores that Seven Eleven operated across the most affected prefectures managed to remain open on March 11 itself, a number that rose to 524 by March 14, 575 by March 21, and reached 826 by March 28 (Seven Eleven: no year). Similarly, reports show that Lawson had about 310 of its 390 stores operating again by March 23, and FamilyMart about 190 of its 250 stores (NKS, 24/3/2011:10).

Yet stores had to reopen with limited product supply, since CVSs, due to limited storage space and a high proportion of fresh merchandise, relied on three to four deliveries a day (Etoh, 2013; Nishikawa, 2011). Freshly prepared food items like salads, lunch sets, or sushi are typically prepared and delivered with a lead time of only $10 \mathrm{~h}$; for processed food items, the lead time is just $7 \mathrm{~h}$ (Namiki, 2011). To maintain an image of freshness, companies label products with very short best-before dates, a policy that proved highly problematic when products no longer reached stores as scheduled (Kamei, 2011). In supplying stores, companies experienced the breakdown of supply lines through damaged distribution centers and production facilities, but also through bottlenecks such as a severe shortage of gasoline for transport vehicles. The disaster led to immediate power outages at stores and distribution centers, and, later, regular scheduled outages to cope with energy shortages. This led to a breakdown of communication systems, leaving companies uncertain about supplies required at production facilities and stores (TRC, 2012; Seven Eleven: no year). There were even reports of supplies being shifted away from disaster areas, when the algorithms of automated order systems interpreted the lack of data from affected areas as a drop in demand. At the same time, systems were registering increased demand from other parts of Japan, where consumers were hoarding products (Hayashi, 2011). Consequently, the president of a leading food wholesaler, Kokubu, described Japan's food logistics system as "fragile as glass" (Gekiryu Magazine, June 2011:69). This assessment of the Japanese distribution system as vulnerable largely mirrors conclusions in the general literature on supply chains and disasters, with many supply chains the world over having moved towards small lot, just-in-time fulfilment (Christopher \& Peck, 2004; Lederman et al., 2009).

While it took companies several months to recover their original logistics infrastructure and supply levels (TRC 2012), companies managed to restore some product supply to stores much earlier by utilizing their nation-wide transport and distribution 
center infrastructure, as well as their strong relationships with major food manufacturers and importers. Companies restored coverage by shifting the boundaries of areas served by still-operating centers outwards into the disaster areas. Seven Eleven was thus able to restore its normal frequency of three deliveries per day to many of its stores as soon as two weeks after the disaster, and with $80 \%$ of its original product range. This fast recovery was attributed to the fact that Seven Eleven had, together with its supply partners, set up a network of production facilities that exclusively supplied to its stores, thus ensuring that the company did not have to compete with other retailers for supplies. It took Lawson and FamilyMart two weeks longer to increase delivery frequency from once to twice daily (NKS E-edition, 30/6/2011; $N K S, 7 / 4 / 2011: 3$ ). Companies also profited from the individual initiative of franchisees, many of whom reopened stores with whatever merchandise was available. Some store owners managed to find alternative supply sources, and while normally franchise headquarters tightly control the merchandise handled by franchisees, franchisees were praised for their initiative after the disaster (Shokuhin Shōgyō May 2011; Seven \& I Holdings, 2011).

In summary, the CVS operations of the leading companies displayed weaknesses in terms of disaster readiness, many of which were inherent to the CVS business model. However, when restoring operations, companies subsequently demonstrated considerable strengths and flexibility (Table 1). While just-in-time supply systems were inhibitors, nation-wide logistics and supply systems, as well as strong collaborative relationships with suppliers and manufacturers, served as facilitators. Reports on the Great Eastern Japan Earthquake also emphasize how the leadership, initiative, and sacrifice of individual franchise owners had been instrumental to overcoming difficulties. This led to proposals that store operation manuals be shortened, and employees and franchisees further empowered, so as to increase resilience to disaster situations (Konbini, May 2011; Sakurai, 2011). This can be interpreted as a call for increased dynamic capabilities in a context in which actors had become highly reliant on, and even somewhat proud of, the existence of automated and routinized procedures. In spite of this, companies began to look at how they could improve their capabilities to sense threats quickly and appropriately, to reconfigure systems accordingly - for example, by changing from pull- to push-based supply systemsand even, when possible, to recognize opportunities that might accompany such situations.

Since 2011, companies have made significant efforts to increase the disaster resilience of their operations. Focusing on bottlenecks first identified during the disaster, companies have tried to address them by, for example, equipping stores with emergency energy backup, ensuring the provision of sufficient gasoline for delivery vehicles, increasing supply sources for bottled drinking water, or preparing emergency plans with logistics partners for quickly shifting products to where they are most needed. Companies have also reviewed their production and distribution center networks to reduce dependence on single facilities, and to increase capacity for emergency situations (NKS sokuho, 2/6/2012; NMJ, 23/1/2013:5; NMJ, 28/11/2012:5; MLIT 2015; Nikkan Kōgyō Shinbun, 31/5/2016). Yet, due to a business model that centers on freshness and just-in-time deliveries, CVSs' ability to regain quick access to stores after disasters remains crucial. In light 


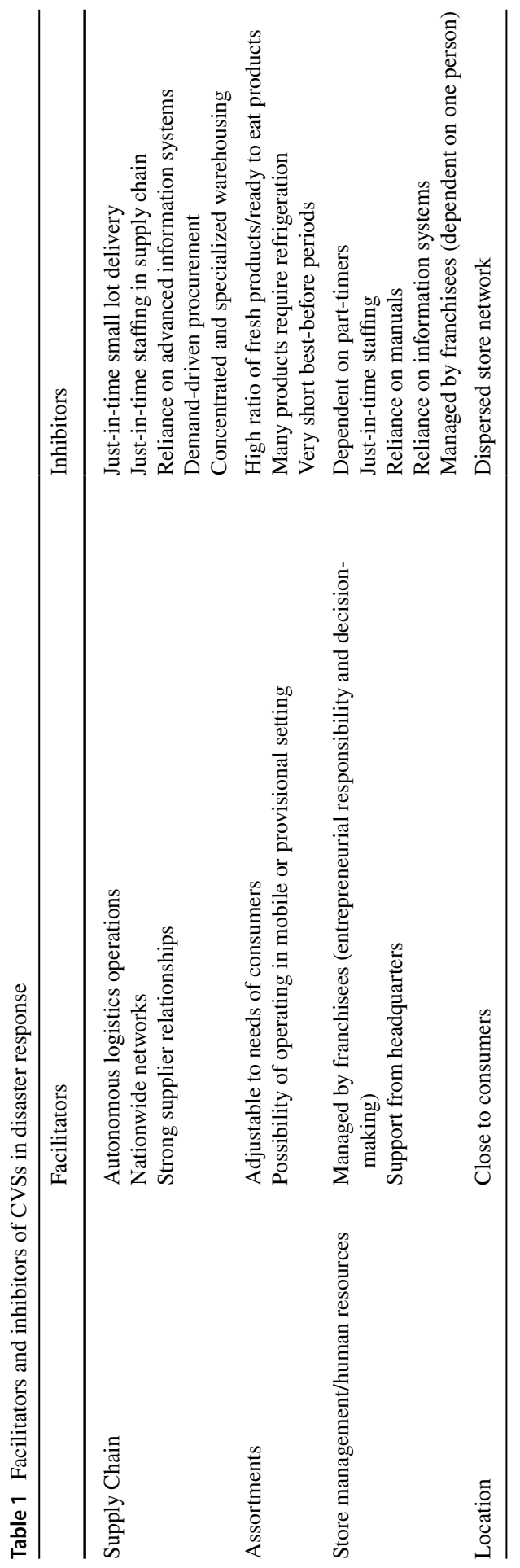


of this, companies have strengthened their cooperation with public actors, here building on calls by both ministerial advisory committees and business associations for an increased integration of the relief efforts of public and private actors (KSKK, 2015; NKS, 26/4/2016:13; Keidanren, 2016). In June 2017, the Japanese government added Japan's leading retailers (among them the three largest CVS chains) to the Disaster Countermeasures Basic Act as "designated public organizations," alongside utility, communication, and transport providers (METI, 2017). The involvement of retailers and logistics companies followed an official decision by policy makers to change initial disaster response from a pull- to a push-based model, proactively "pushing" relief goods into disaster zones instead of waiting for "pull" signals. In July 2018, after large areas of western Japan had been hit by torrential rain, Japan's Self-Defense Forces assisted in transporting CVS delivery vehicles across flooded areas, likely a first in disaster relief (The Sankei News, 22 July 2018).

The events of the 2011 disaster also helped companies gain acceptance as essential infrastructure providers in and by communities themselves. CVS companies assumed a highly visible role in the recovery process, and this role has come to occupy a much larger place in public memory than initial product supply issues. Companies conducted outreach to consumers through mobile or modular stores in newly erected temporary settlements, which also fulfilled communal functions (Asano, 2011). A store by FamilyMart, for example, was only one-third the size of a normal store, and carried fewer items, but offered a space for meetings. The store also rented out three small cars, had a small library of books and DVDs, and provided a space for town leadership to counsel citizens. To create links to the community, FamilyMart selected a store manager from a local family of shopowners (Asano, 2011). Seven Eleven activated plans for a mobile CVS. Once the stores were implemented, the company found that, although people in evacuation centers were generally well-cared for by governmental and volunteer organizations, their stores saw unexpected demand from people who had remained in their homes. The company also discovered high demand for liquor, confectionery, or cigarettes, items that were not included in public emergency supplies. A mobile store operator reported improved standing in the local community after the crisis, and claimed that customers who had not frequented his regular store began to do so after visiting the mobile store (Gekiryu Magazine, November 2011).

\section{Assuming a role in solving long-term challenges of an aging and shrinking population}

In light of the issues that our country is struggling with, such as the shrinking and aging population, vitalization of the economy, the support and enhancement of local communities, environmental issues, the expectations towards convenience stores are high. (Ministry of Economics, Trade and Industry [METI], 2014)

Graph 1 shows the dramatic change in the age composition of Japan's population, and the growth of CVSs since their introduction in the 1970s. Since the mid-1990s, 


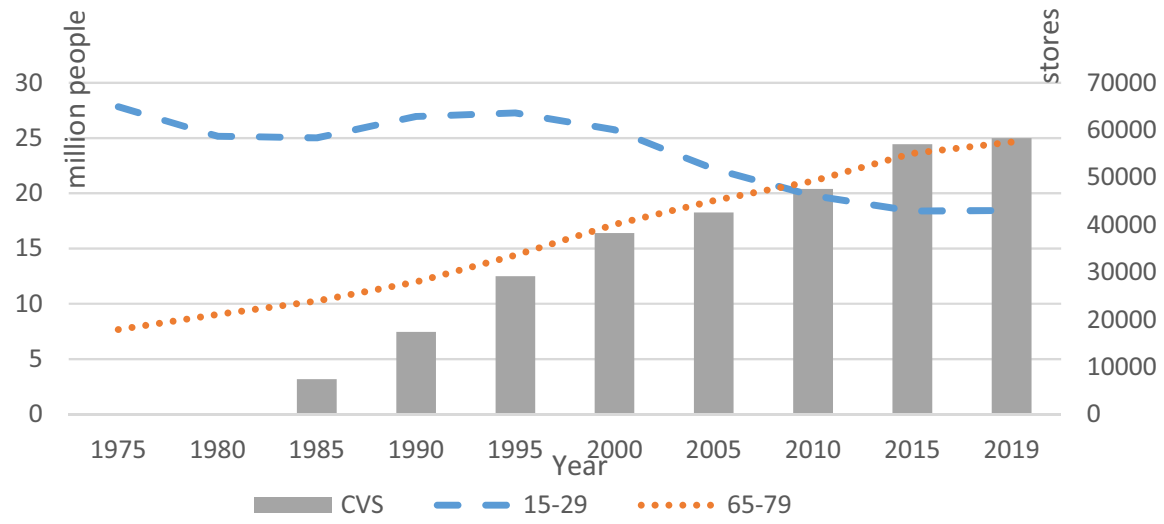

Graph 1 Demographic development and development of number of convenience stores. Population data from Statistics Bureau of Japan, http://www.stat.go.jp/data/jinsui/2.html. Store numbers from Survey on Franchise Chains at Japan Franchise Association, http://www.jfa-fc.or.jp/particle/29.html

the number of people between 15 and 30 years of age-the core group of CVS consumers-has been decreasing, and the number of people above 65 has significantly increased, overtaking the number of consumers in the younger age groups in 2010. Companies hoping to grow further therefore had to find ways to develop new locations and widen their customer base. In terms of new locations, companies have significantly increased their engagement in non-metropolitan areas, which are often less densely inhabited areas with older populations (Table 2).

To appeal to elderly consumers, companies have begun to offer more fresh produce and ingredients for cooking meals at home, as well as products and meals preferred by elderly consumers - for example, by replacing meat with fish and vegetables (Kato, 2016). In addition, companies are experimenting with new services and new store formats:

- Seven Eleven has been running a meal delivery service, "Seven Meal," since 2000, and started offering home delivery of products in Hokkaido in 2017 (NKS, 11/5/2018:13).

Table 2 Inhabitants per convenience store of three dominant CVS Chains (2010 and 2019)

\begin{tabular}{|c|c|c|c|c|}
\hline \multirow[t]{2}{*}{ Prefectures } & \multicolumn{2}{|c|}{$\begin{array}{l}\text { Inhabitants per } \\
\text { store }\end{array}$} & \multicolumn{2}{|c|}{$\begin{array}{l}\text { Ratio inhabitants above } \\
65 \text { years old }\end{array}$} \\
\hline & 2010 & 2019 & 2015 & Projection 2040 \\
\hline Average across all 47 prefectures & 4722 & 2455 & 28.3 & 37.2 \\
\hline Tokyo & 3212 & 2017 & 22.7 & 33.5 \\
\hline $\begin{array}{l}\text { Average of } 3 \text { most densely populated prefectures } \\
\text { Tokyo, Osaka, Kanagawa (Yokohama) }\end{array}$ & 3865 & 2327 & 24.3 & 34.8 \\
\hline Average of 10 least densely populated prefectures & 5036 & 2409 & 30.8 & 40.0 \\
\hline
\end{tabular}

Calculations based on population data from Statistics Bureau of Japan, http://www.stat.go.jp. Prefecture data for stores by Seven Eleven, FamilyMart and Lawson Todōfuken Dētā Rankingu (Prefectural Data Ranking) https://uub.jp/pdr/m/seven.html 
- To cater to the elderly, Lawson promised to reduce salt content in its meals by 20\% between 2017 and 2021 (NMJ, 27/3/2019:11).

- Seven Eleven agreed to cooperate with Fukuoka Prefecture in providing elderly inhabitants with employment opportunities, e.g., hiring elderly people to deliver food to other elderly people, and to report on their wellbeing while doing so (NKS Kyushu, 26/6/2014-e:13).

- FamilyMart, in cooperation with Tokyo's government, pledged to properly label low-nutrient meals in its 2400 stores in Tokyo to fight frailty in the elderly population (NKS Tokyo, 1/11/2019:15).

- CVS operators, in cooperation with Osaka Prefecture, agreed to train employees to spot and support people with dementia who seem to be in trouble (NKS Osaka, 18/9/2015e:19).

- FamilyMart is opening stores with counseling counters for the elderly and their families, in collaboration with elderly care providers ( $N M J, 8 / 3 / 2018: 15)$.

- Lawson, together with a housing developer, set up a store equipped with a community space in a suburban area in Kanagawa Prefecture, where volunteers organize events and help the elderly with shopping and using CVS services (NKS Kanagawa, 30/10/2019:26).

- To serve elderly people with mobility difficulties, Seven Eleven has begun to deploy mobile stores in Hikarigaoka, a housing development for senior citizens in Tokyo (NKS Tokyo, 10/11/2018:15).

- Seven Eleven is working with Keikyu Railway to provide delivery services to aging populations in residential areas along the railway line (NMJ, 24/1/2018:4).

- Family Mart opened a store in Fukui Prefecture, in collaboration with a regional cooperative and the local municipality, to serve a depopulating community with just 1800 people (NKS Hokuriku, 1/2/2018:8).

Companies are thus striving to maintain and even expand their leading role in Japanese retailing. However, in doing so, the number of stakeholders involved in CVS operations has further increased, and now includes public actors. CVS companies have concluded service contracts and comprehensive memoranda of understanding with cities and prefectures, in which the intention that CVSs contribute widely is clearly voiced (Kodama, 2018; Tsukui, 2017). The Ministry of Economy, Trade and Industry (METI) set up a study committee in 2014 to investigate the potential economic and social role of CVSs. In 2018, the government relaxed zoning laws to ease the opening of stores selling daily necessities in residential areas (NMJ, 22/7/2018:15).

But while the CVS industry managed to improve its public standing considerably in the wake of the 2011 disaster, this status has come into question again. As another consequence of the aging population, the CVS industry is facing a labor shortage. This has put a severe strain on franchise owners, many of whom run more than one store, are advancing in age themselves, and oversee store operations that have become more complex both through the addition of services and increased demands from communities. In May 2019, a CVS owner in Osaka made headlines beyond Japan by closing his store for several hours at night, thereby putting himself in violation of his franchise contract (New York Times, 30 December 2019). The franchise 
operator initially reacted harshly, but, following a public outcry, CVS operators are now trialing shorter working hours in some stores. Soon after the incident, the Japanese government installed an advisory committee to review this issue. The proposal for its final report again emphasized the heightened importance of CVSs' roles in communities, but also acknowledged the challenges that store owners face in fulfilling significantly increased expectations. The report recommends recognizing the diversity that has developed within store networks, and demands that CVS companies allow for flexibility with regards to opening hours and services provided, as well as when deciding on royalties charged to franchisees (METI, 2020b). This position was further reinforced by the Fair Trade Commission issuing another report on convenience stores in September 2020, which again questioned the control of franchise headquarters over the operations of their franchisees in terms of opening hours and prices (NMJ 7/9/2020:1). Shorter opening hours, however, mean that "the lights are no longer always on" in the CVS. CVS headquarters are looking at potentially introducing increased automation to relieve storeowners. However, systematic automation and the reduction of store personnel would conflict with the positioning of stores as social infrastructure, as well as their potential as support centers in times of disaster.

The Covid-19 crisis of 2020 put further stress on the CVS industry, and again demonstrated the complexity of convenience store operations. Stores in central business and shopping districts saw significant drops in sales, with workers and shoppers largely staying at home. Stores in residential areas found themselves competing with supermarkets for everyday products and losing late night customers (NKS, 23/7/2020:13). At the same time, while facing demands to support consumers in their neighborhoods, franchisees still needed to ensure the safety of shoppers and staff. Decisions by franchisees to close facilities such as toilets or eating corners, or to remove trash bins, complicated the role of CVS as public infrastructure in times of crisis, and led to further conflicts between headquarters and franchisees (NSS, 7/7/2020:9). At the same time, part-time workers losing jobs elsewhere, especially in the restaurant sector, has somewhat eased the labor shortage in the industry and thus the pressure to find solutions in terms of opening hours, with some stores even returning to around-the-clock operations (NKS, 20/10/2020:12). However, there remain worries that, due to increased demands and shrinking margins, store owners will not renew their franchise contracts, $30 \%$ of which are up for renewal within the next five years (NMJ, 4/12/2020:1). The Covid-19 crisis has thus led to further calls for companies to review their business models, especially in terms of their treatment of franchisees, yet has also led to initiatives, such as 30-min home deliveries, that further complicate the running of stores (NMJ, 23/9/2020:11).

\section{Discussion}

The above outline of the development of CVSs over time reflects the intensive and developing discourse about the role of CVS in Japanese society. Despite the vulnerability of CVS companies to disaster due to their just-in-time business model, policy makers see CVSs as playing a major role in providing products and services 
(public or private) in situations of disaster, thereby signaling trust in their capabilities to recover supply systems. Policy makers have also expressed expectations that CVSs serve an aging population and people in depopulating areas. CVS operators themselves have adjusted their business models accordingly, strengthening the disaster resilience of their systems and adding products and services that cater to the needs of depopulating areas and elderly customers. Returning to the initial literature review, this concluding discussion will use the case of Japan's CVSs to develop proposals with regards to the motivations, the involvement of stakeholders, and the changes to the business models and necessary capabilities of companies that aim to engage with grand societal challenges.

Hamann et al. (2020) have proposed adding the strengthening of community resilience to the previously described motivations for companies' engagement with grand challenges, such as increasing competitiveness, establishing legitimacy, or demonstrating corporate responsibility. Striving to protect their own assets and markets and create new opportunities can motivate companies to take on tasks and provide services that public actors cannot afford, or are no longer able, to provide. In terms of maintaining competitiveness, a growth in the number of CVSs and a decreasing number of younger customers motivated CVS operators to widen their customer base and to change their business models accordingly. In terms of creating legitimacy, it was no coincidence that companies declared their stores as social infrastructure and safety stations where "the lights are always on" precisely at a time when some municipalities were considering regulating the industry (Japan Times, 17 July 2008). Companies are heavily emphasizing such positive features in their CSR reporting, even if it can be argued that creating employment or providing a feeling of safety for communities at night are just an outcome of the CVS business model and not selfless contributions to society (Ishihara, 2019). However, public bodies in Japan are finding it increasingly difficult to offer comprehensive services on the basis of public funding, be that due to increasing demands from a less mobile, elderly population, shrinking local tax income, or decreasing support from central government funds. In this context, activities by CVS operators in terms of disaster preparedness or services and products offered contribute to local resilience, and consequently to keeping aging and shrinking communities viable places to live (Hamann et al., 2020). Yet CVS companies are corporate, profit-oriented entities, and therefore their efforts to collaborate with other businesses or public actors can be interpreted as a way of generating revenue and sharing the costs of offering increased community support. In this respect, both companies and communities are still experimenting, and it remains to be seen whether these initiatives will allow CVS companies to maintain or even develop new stores in shrinking communities, for which coverage has increased but is still, in many non-metropolitan areas, deemed insufficient (Takemoto, 2016). In summary, I propose that the motivations of CVS companies have evolved beyond competitiveness, CSR, and legitimacy considerations to include an interest in keeping local communities viable places to live in, and consequently viable places in which to do business and generate profits.

McKnight and Linnenluecke (2016) have suggested looking at stakeholders and classifying companies' responses to disasters as either firm- or community-centric. I propose extending this approach to the way that Japanese CVS companies deal 
with societal challenges, and have shown how companies have moved from initially firm-centric to competitor-centric business models, and now increasingly to community-centric models. However, CVS headquarters, in the process of trying to satisfy the interests of an increasing number of stakeholders, seem to have somewhat neglected the interests of initial stakeholders-the franchisees that run the stores, and who shoulder much of the business risks of doing so.

In terms of capabilities, I propose that engagement with societal challenges demands higher-level capabilities. CVS chains have previously aimed at reducing uncertainty and complexity as much as possible through the use of standardization, manuals, technology, and information systems. However, the events following the 2011 earthquake demonstrated the need for headquarters and store owners to be able to make decisions and act under conditions of uncertainty. Heavy reliance on systems and routines enabled companies to attract franchisees with no retail experience, including those that employ part-timers with little training. However, modeling the CVS as social infrastructure (e.g., to serve aging populations) has taken the CVS beyond a system that simply provides products and therefore can be easily automated. Offering toilets and meeting spaces requires supervision and maintenance: storeowners have to be able to make decisions in times of crisis as to how to engage best with surrounding communities, communities whose needs differ substantially across store locations. Finally, interaction with customers has gained in importance. While customer interaction was once largely anonymous, employees now have to counsel elderly customers, who regard CVS as places that can provide them with human interaction (Igarashi et al., 2018). Therefore, storeowners and employees need to learn how to react flexibly to the needs of people in their communities, and franchise headquarters need to learn how to allow for more autonomy and initiative on the part of store owners, and thereby to manage increased diversity in their systems.

Bringing these different perspectives on the development of the Japanese CVS together, I propose that the increasing engagement of CVS with Japan's grand societal challenges has thrown a previously carefully balanced business model off balance. This owes both to an increase in the number of involved stakeholders and their interests and, at the same time, demands for higher-level capabilities. This does not mean that Japan's CVS companies could or should have ignored a changing environment and developing threats. Yet I propose that, in pursuing growth and responding to societal challenges, CVS companies could have calibrated this balance more carefully, especially with regards to the role and capabilities of franchisees. Interestingly, in the debate on the challenges that CVSs face, the example of Secoma, which currently runs a "Seicomart" CVSs in Hokkaido, is receiving attention. The company has shifted from a franchise model to running stores directly by employed store managers. It is also operating its own logistics, and even some production facilities that supply its stores (Abe et al., 2019; NMJ 24/7/2019:4). This integrated model, while probably less profitable than the networked model of its larger competitors (NKS Hokkaido, 10/1/2020:1), has allowed the company to operate stores in very remote and sparsely populated areas, and to circumvent some of the problems that the larger CVS chains face in satisfying their many stakeholders. 


\section{Conclusions}

This article has taken the case of the Japanese CVS to demonstrate how companies' involvement with grand challenges can become an essential part of their business models. Outlining the role of CVS in a society vulnerable to the sudden and unexpected shock of disaster, as well as the slow-moving and predictable threat of an aging population, the case study has shown how, when faced with grand challenges and following the decision to engage with them, companies' business models, necessary capabilities, and stakeholder involvement change significantly. These factors should therefore be investigated together when discussing companies' engagement with grand challenges, thereby advancing existing research. The case has also shown how and why an investigation should go beyond business models to include the surrounding societal and political discourses, since these significantly influence the decision-making of companies.

In addition to contributing to the study of companies' responses to grand challenges in general, the case of Japanese CVS companies and their responses to both natural disasters and an aging population can also provide more specific insights for companies and policy makers. While they are certainly not without problems, Japanese CVS companies have overall shown themselves to be very creative in updating their business models and creating partnerships with policy makers and other businesses in the process of doing so. Many of these initiatives are still in relatively early stages, yet deserve the attention of policy makers and businesses in other countries that are increasingly facing similar issues with respect to providing services and goods to, and increasing disaster resilience in, areas with aging and shrinking populations. There seems to be a consensus that overcoming these issues will require the involvement of the private sector, and in this regard the strategies of technologically advanced Japanese CVS companies might provide some valuable lessons.

Although I have made an effort to examine a significant time period and advance the discussion of various relevant factors, it must be acknowledged that not all possible questions have been answered in detail. For example, in terms of the motivations of CVS companies, it has been shown that distinguishing between possible motivations contributes to a better understanding of developments in the industry, but it would be interesting to conduct a deeper and more systematic study into the evolving motivations of CVS companies. The same would be true for CVS franchisees' own views on their increased involvement in local communities.

Another topic that would deserve a more detailed investigation is the relationship between the CVS sector and the state, research on which would contribute to the long-ongoing discussion about the role of the state in Japan's economic development. The Japanese state has a long tradition of intervening in the retail sector, alternating between periods of less and more intensive interventions. Historically, many such measures were restrictive, insofar as the activities of large national retailers were primarily seen as a threat to local economic development and vitality (Suzuki, 1993). Based on their potential contributions to Japan's grand challenges, however, policy makers and regulators seem to regard the role of national large retailers more positively at present. It would therefore be interesting to investigate in more 
depth how local policy makers balance this closer relationship with national retailers with their continued commitment to catering to the interests of local business communities.

Finally, a comment on the relevance of the findings of this article for internationalizing companies, especially retailers. Studies on retail internationalization have always emphasized the importance of carefully adjusting to local conditions, and have highlighted this as a major potential difference when compared with other industries (Alexander \& Myers, 2000; Dawson, 1994; Wrigley et al., 2005). This article has shown the very complex level of engagement that stakeholders have come to demand from retailers in light of Japan's societal challenges. As shown, demonstrating the willingness and capabilities to participate in such challenges, e.g., in disaster relief, can significantly help companies build acceptance in local communities. But doing so requires considerable resources, capabilities, and knowledge of the local landscape. It would therefore be interesting to study whether retailers that have internationalized have considered this, and whether and how they have developed the relevant capabilities to engage with local communities in overseas markets. Of course, this also applies to Japanese CVS companies themselves, some of whom are already operating substantial store networks overseas, especially in other Asian countries that have aging populations and are also regularly threatened by natural disasters.

Acknowledgements I would like to thank the anonymous reviewers for their detailed and encouraging comments and suggestions. I acknowledge support from the Publication Support Fund of the Department of Japanese Studies of the National University of Singapore.

\section{Declarations}

Conflict of interest On behalf of all authors, the corresponding author states that there is no conflict of interest.

\section{References}

Abe, T., Yamaguchi, H., \& Ohara, T. (2019). Sekoma: Konbini kara sōgō ryūtsūgyō e no tenkan (Secoma: Converting from convenience stores to general distribution business). Hokkaido Daigaku Daigakuin Keizaigaku Kenkyūin Discussion Paper, Series B, 170, 1-37. http://hdl.handle.net/2115/72898

Alexander, N., \& Myers, H. (2000). The retail internationalisation process. International Marketing Review, 17(4/5), 334-353.

Asano, K. (2011). Komyunitei no kaku toshite katsuyaku suru Famiriimaato Kawamatachō ten (The Family Mart Kawamatacho store that flourishes as the center of the community). Konbini, August, 23-25.

Ballesteros, L., Useem, M., \& Wry, T. (2017). Masters of disasters? An empirical analysis of how societies benefit from corporate disaster aid. Academy of Management Journal, 60(5), 1682-1708.

Bansal, P., \& Roth, K. (2000). Why companies go green: A model of ecological responsiveness. Academy of Management Journal, 43(4), 717-736.

Cabinet Office. (2017). White Paper Disaster Management in Japan 2017. Retrieved July 10, 2020 from http://www.bousai.go.jp/kyoiku/panf/pdf/WP2017_DM_Full_Version.pdf 
Cabinet Office (Naikakufu). (2019a). Reiwa Gannen-ban Kōrei Shakai Hakusho (Whitepaper for the aging society 2019). Retrieved January 12, 2020 from http://www.cao.go.jp/kourei/whitepaper/w2019/zenbun/01pdf_index.html

Cabinet Office. (2019b). White Paper Disaster Management in Japan 2017. Retrieved July 10, 2020 from http://www.bousai.go.jp/kaigirep/hakusho/pdf/R1_hakusho_english.pdf

Capitanio, M. (2018). The role of urban design in Tokyo's shrinking peripheral areas: The case of Tama New Town. International Journal of Architectural Research, 12(1), 112-132.

Carden, W. A. (2009). Sound and fury: Rhetoric and rebound after Katrina. Journal of Business Valuation and Economic Loss Analysis, 4(2), 1-12.

Chand, M., \& Tung, R. L. (2014). The aging of the world's population and its effects on global business. Academy of Management Perspectives, 28(4), 409-429.

Christopher, M., \& Peck, H. (2004). Building the resilient supply chain. International Journal of Logistics Management, 15(2), 1-14.

Dawson, J. (1994). Internationalization of retailing operations. Journal of Marketing Management, 10(4), 267-282.

Elis, V. (2011). Rural depopulation and economic shrinkage in Japan: What can affected municipalities do about it? In F. Coulmas \& R. Lützeler (Eds.), Imploding Populations in Japan and Germany (pp. 443-460). Brill.

Ergun, Ö., Heier Stamm, J. L., Keskinocak, P., \& Swann, J. L. (2010). Waffle House restaurants hurricane response: A case study. International Journal of Production Economics, 126(1), 111-120.

Ergun, Ö., Karakus, G., Kerl, P., Keskinocak, P., Swann, J. L., Villarreal, M., \& Drake, M. J. (2013). Disaster response planning in the private sector and the role of operations research. In J. Hermann (Ed.), Handbook of Operations Research for Homeland Security (pp. 197-217). Springer.

Etoh, K. (2013). Higashi Nihon Daishinsai ato ni okeru shōgyō butsuryū ni tsuite (Commercial logistics after the Great East Japan Earthquake). Unsō Seisaku Kenkyū, 16(1), 54-58.

Ferraro, F., Etzion, D., \& Gehman, J. (2015). Tackling grand challenges pragmatically: Robust action revisited. Organization Studies, 36(3), 363-390.

Gekiryru Magazine. (June 2011). Gurasu no ryūtsū shisutemu hōkai de kinkyūji no taisai saikōchiku wa hisshi (The breakdown of the glass-like distribution system makes it necessary to rebuild the system for times of emergencies). 68-71.

Gekiryu Magazine. (November 2011). Hisaichi de hana hiraita otodoke no soosharu bijinesu (The registered social business that blossomed in the disaster area). 50-53.

George, G., Howard-Grenville, J., Joshi, A., \& Tihanyi, L. (2016). Understanding and tackling societal grand challenges through management research. Academy of Management Journal, 59(6), 1880-1895.

Hamann, R., Makaula, L., Ziervogel, G., Shearing, C., \& Zhang, A. (2020). Strategic responses to grand challenges: Why and how corporations build community resilience. Journal of Business Ethics, 161, $835-853$.

Harada, K., Sugisawa, H., Sugihara, Y., Yanagisawa, S., \& Shimmei, M. (2019). Perceived age discrimination and job satisfaction among older employed men in Japan. The International Journal of Aging and Human Development, 89(3), 294-310.

Hayashi, A. (2011). BCP gurūpu no BCP (The BCP of the CGC Group). Shokuhin Shogyo, September, 65-67.

Horwitz, S. (2009). Wal-Mart to the rescue: Private enterprise's response to Hurricane Katrina. The Independent Review, 13(4), 511-528.

Igarashi, A., Matsumoto, H., Suzuki, M., Hamada, T., Aoki, S., Aburayama, K., Murata, S., Suzuki, M., Yasui, H., \& Yamamoto-Mitani. (2018). Hōmon kaigo sābisu o riyō suru kōreisha no konbiniensusutoa riyō no jittai (Use of CVS in community-dwelling older adults who utilize home help services offered under the long-term care insurance). Rōnen Shakai Kagaku, 40(3), 283-291.

Ishiguro, K. (2014). Food access among elderly Japanese people. Asian Social Work and Policy Review, $8(3), 275-279$.

Ishihara, T. (2011). Kourigyō kara mita kaimono nanmin (Can retailers contribute to the consumers with limited mobility). Toshi Keikaku, 60(6), 46-49.

Ishihara, T. (2019). Kourigyō no gaibusei to chiiki kōken (Externality of retailing and regional contribution). Māketingu Janāru, 38(3), 6-16.

Japan Times. (17 July 2008). Are 24-hour shops a waste of energy? Retrieved February 12, 2019 from http://www.japantimes.co.jp/news/2008/07/17/national/are-24-hour-shops-a-waste-of-energy/ 
JFA (Nihon Furanchaizu Chēn Kyōkai). (2011). "Shakai infura toshite no konbiniensu sutoa sengen" shinchoku jōkyō ("Convenience store as social infrastructure declaration" - progress report). Retrieved June 20, 2019 from http://www.jfa-fc.or.jp/folder/1/img/20110810101959.pdf

JFA (Nihon Furanchaizu Chēn Kyōkai). (2020). JFA Konbiniensu Sutoa Chōsa Geppō (JFA monthly statistics of CVS). 20 January. Retrieved February 7, 2020, from http://www.jfa-fc.or.jp/particle/320. html

Kaido, K., \& Tsuruta, Y. (2012). Sustainable suburbia through the perspective of lower density and shrinkage: The case study of the Nagoya metropolitan region in Japan. In R. Ganser \& R. Piro (Eds.), Parallel Patterns of Shrinking Cities and Urban Growth (pp. 145-163). Routledge.

Kamei, R. (2011). Butsuryū - 'chiiki seisan', 'kigen hyōshi no kanwa' 'zenkoku kara no chōtatsu taisei' de rojisutikusu wa kaizen suru (Logistics - reforming logistics through local production, changing the best-before-date rule and coming up with a system for nation-wide procurement). Hanbai Kakushin, May, 45-47.

Kato, N. (2016). Kōreika jidai no shokuhin kaihatsu no hōkō-sei - konbini no shoku maaketingu o chūshin ni (Direction of food development in the age of aging: Focusing on the food marketing of CVS). Bimi Gijutsu Gakkaishi, 14(2), 36-42.

Kawabata, M., Matsumoto, S., Sano, K., \& Tsuchiya, S. (2010). Car passenger transport and barriers to community bus use in a mountainous underpopulated region in Japan. Journal of the Eastern Asia Society for Transportation Studies, 8, 497-510.

Kawabe, N. (2013). Dai 2 sedai no konbini-ron (Theory of the CVS of the next generation). Keiei Ronsh $\bar{u}$ (Bunkyo Gakuin University), 23(1), 9-35.

Keidanren (Nihon Keizai Dantai Rengō-kai). (2016). Daikibo saigai e no taiō ni okeru kanmin renkei no kyōka ni mukete (Toward strengthening public-private partnership in response to large-scale disasters). 19 April 2016. Retrieved March 20, 2019 from https://www.keidanren.or.jp/policy/2016/028_ honbun.pdf

Kodama, H. (2018). Jichitai ni okeru kōmin renkei no genjō to kadai: - Tochigi ken to Kōbe-shi no jirei hikaku kara (Public private partnership in local governments: A comparison between Tochigi and Kobe). Hakuoh Hogaku: Hakuoh Review of Law and Politics, 24(3), 177-219.

Konbini. (May 2011). Konbini no tsuyosa to yowasa, (Strengths and weaknesses of conveniences stores). $12-17$.

Koyama, S. (1993). Kouri gyōtai no shinka (Evolution of retail formats). In Nihon Keizai Shinbunsha (Ed), Ryūtsū Gendaishi (Contemporary history of distribution): (pp. 20-39). Nihon Keizai Shinbunsha.

KSKK (Konbiniensu sutoa no keizai / shakai teki no yakuwari kenkyū-kai). (2015). Konbiniensu sutoa no keizai / shakai teki no yakuwari ni kansuru chōsa hōkokusho (Research report on the role of CVS for society and economy). March 2015. Retrieved March 20, 2019 from http://www.meti.go.jp/meti_ lib/report/2015fy/000642.pdf

Kulik, C. T., Perera, S., \& Cregan, C. (2016). Engage me: The mature-age worker and stereotype threat. Academy of Management Journal, 59(6), 2132-2156.

Kulik, C. T., Ryan, S., Harper, S., \& George, G. (2014). Aging populations and management. Academy of Management Journal, 57(4), 929-935.

Larke, R., \& Causton, M. (2005). Japan: A Modern Retail Superpower. Palgrave Macmillan.

Lawson Inc. (2016). Lawson Integrated Report 2016, Retrieved October 10, 2019 from http://lawson.jp/ en/ir/library/pdf/annual_report/ar_2016_e_5.pdf

Lederman, R, Kurnia, S., \& Lederman, J. (2009). Designing supply chain systems to cope with catastrophes. Pacific Asia Conference on Information Systems (PACIS) 2009 Proceedings.

Liu, C., Black, W. C., Lawrence, F. C., \& Garrison, M. E. B. (2012). Post-disaster coping and recovery: The role of perceived changes in the retail facilities. Journal of Business Research, 65(5), 641-647.

Martin, A., \& Williams, J. (2014). Public-private partnership from theory to practice: Walgreens and the Boston Public Health Commission supporting each other before and after the Boston bombings. Journal of Business Continuity \& Emergency Planning, 7(3), 205-220.

Martine, J., \& Jaussaud, J. (2018). Prolonging working life in Japan: Issues and practices for elderly employment in an aging society. Contemporary Japan, 30(2), 227-242.

Marutschke, D. (2012). Continuous Improvement Strategies. Japanese Convenience Store Systems. Palgrave Macmillan.

Matanle, P., \& Sato, Y. (2010). Coming soon to a city near you! Learning to live 'beyond growth' in Japan's shrinking regions. Social Science Japan Journal, 13(2), 187-210. 
McKnight, B., \& Linnenluecke, M. K. (2016). How firm responses to natural disasters strengthen community resilience: A stakeholder-based perspective. Organization \& Environment, 29(3), 290-307.

McKnight, B., \& Linnenluecke, M. K. (2019). Patterns of firm responses to different types of natural disasters. Business \& Society, 58(4), 813-840.

MAFF. (2014). Shokuhin sangyō jigyōsha no tame no renkei kunren manyuaru (Collaboration training manual for food industry operators). March 2014. Retrieved December 20, 2020 from http:// www.maff.go.jp/j/zyukyu/anpo/pdf/manual.pdf

METI. (2014). Konbiniensu sutoa no keizai / shakai teki no yakuwari ni tsuite (About the role of CVS for society and economy). September 2016. Retrieved March 20, 2019, from https://www.meti. go.jp/committee/kenkyukai/shoryu/convenience/pdf/001_03_00.pdf

METI (2017). Saigai taisaku kihon-hō' ni motodzuku shitei kōkyō kikan ni shitei sa remashita, 27 June 2017. Retrieved June 14, 2019 from http://www.meti.go.jp/press/2017/06/20170627001/ 20170627001.html

METI (2020a). Konbiniensu sutoa shōhin hanbaigaku tō oyobi zen'nen (Sales by product at CVS and year-on-year comparison). Retrieved July 15, 2020 from http://www.meti.go.jp/statistics/tyo/ syoudou/result-2/index.html

METI. (2020b). 'Aratana konbini no arikata kentōkai' hōkoku-sho, - Reiwa no jidai ni okeru konbini no kakushin ni mukete - an (Report of the investigation committee about the way of the future CVS, towards a changed CVS for the Reiwa Age, Proposal), 6 February 2020, Retrieved February 10, 2020 from http://www.meti.go.jp/shingikai/mono_info_service/new_cvs/pdf/005_02_00. pdf

Meyer-Ohle, H. (2003). Innovation and Dynamics in Japanese retailing. Palgrave Macmillan.

MLIT. (2015). Ninushi to butsuryū jigyōsha ga renkei shita BCP sakutei sokushin ni kansuru kentōkai hōkoku-sho (Report of the study group on BCP through the collaboration between shippers and logistics companies). March 2015. Retrieved December 20, 2020, from http://www.mlit.go.jp/ seisakutokatsu/freight/seisakutokatsu_freight_tk2_000014.html

Namiki, Y. (2011). Konbini no kadai o kangaeru (Thinking about the problems of CVS). Konbini, June, 21-25.

New York Times. (30 December 2019). A 7-Eleven in Japan might close for a day. Yes, that's a big deal. Retrieved February 20, 2019 from http://www.nytimes.com/2019/12/30/business/7-elevenjapan-work.html

Nishida, M. \& Yamamoto, N. (2015). Konbini bentō no eiyōka oyobi shokuhin kōsei ni kansuru chōsa (Research of nutrition value and food composition in the boxed meals sold at CVS). Wakayama Daigaku Kyōiku Gakubu Kiyō 65(no number), 151-156.

Nishikawa, R. (2011). Ryūtsūgyō no higai to miekita kadai (The problems that can be seen through the damage that occurred in the distribution industry). Hanbai Kakushin, April, 73-75.

Nogimura, T. (2015). Wagakuni no konbini kisei-ron no kentō: māketingu chaneru-ron kara no ichikōsatsu (A Review of the controversy on CVS industry regulation in Japan). Nihon Keiei Shindan Gakkai Ronshū, 15, 93-98.

Sakurai, T. (2011). Tenpo zukuri, shōhin chōtatsu, kigyō bunka o imakoso minaosō (Let's now review the way that stores are built, products are procured and corporate cultures). Hanbai Kakushin, May, 38-41.

SIJ (Sebun-Irebun Japan). (1992). Sebun-Irebun Japan - owari naki inobeeshon (Seven Eleven Japan - Never ending innovation). Sebun-Irebun Japan.

Seven \& I Holdings. (2011). ‘Higashi Nihon daishinsai’ ni tomonau Sebun - irebun no genkyō to taiō ni tsuite (Current status and response of Seven-Eleven following the Great East Japan Earthquake). Press release 7 April 2011. Retrieved February 10, 2019 from http://www.7andi.com/ library/dbps_data/_template_/_res/company/news/pdf/2011/2011-0407-2009.pdf

Seven Eleven Japan (no year). Higashi Nihon daishinsai no fukkō shien (Support for reconstruction after the Great East Japan Earthquake). Retrieved August 15, 2020 from https://www.sej.co.jp/csr/contr ibution/reconstruction.html

Shigeru, D., \& Araki, H. (2008). Konbini keiei to kankyō (Management of a CVS and the environment). Kyōto Kyōiku Daigaku Kankyō Kyōiku Kenkyū Nenpō, 16, 99-114.

Shokuhin Shōgyō. (May 2011). Ion gurupu - Tenpomō, butsuryūmō, kaihatsu shōhin de zenryoku shien (Aeon Group - supporting with all the power of the store network, logistics network and self-developed products). 28-29. 
Stewart, G. T., Kolluru, R., \& Smith, M. (2009). Leveraging public-private partnerships to improve community resilience in times of disaster. International Journal of Physical Distribution \& Logistics Management, 39(5), 343-364.

Suzuki, Y. (1993). Daitenhō no hensen (Changing Large Store Law). In Nihon Keizai Shinbunsha (Ed), Ryūtsū Gendaishi (Contemporary history of distribution): (pp. 191-210). Nihon Keizai Shinbunsha.

Takemoto, R. (2016). Konbini Nanmin (CVS refugees). Chuo Koronsha.

Teece, D. J. (2007). Explicating dynamic capabilities: The nature and microfoundations of (sustainable) enterprise performance. Strategic Management Journal, 28(13), 1319-1350.

The Sankei News. (22 July 2018). [Nishi Nihon gōu] goei-kan `ka ga’ no yokujō muryō kaihō nado, jigen no kukyō ni kaiji no katsudō tsuzuku (Heavy Rain in West Japan - the activities of the maritime self-defense forces continue within the spreading trouble, such as the vessel Kaga opens its baths for free). Retrieved March 20, 2019 from http://www.sankei.com/west/news/180722/wst1807220 008-n1.html

Tierney, K. J. (2006). Businesses and disasters: Vulnerability, impacts, and recovery. In R. Havidán, E. L. Quarantelli, \& R. R. Dynes (Eds.), Handbook of Disaster Research (pp. 275-296). Springer.

TRC (Tōhoku Daigaku Rojisutikusu Chōsa-dan) (2012). Higashi Nihon daishinsai-go no rojisutikusu ni kansuru kiroku to kaiseki (Record and analysis of logistics after the Great East Japan Earthquake). Retrieved August 15, 2020 from http://www.plan.civil.tohoku.ac.jp/ akamatsu/Publications/PDF/ Logistics-Intrm_Rprt-v121101.pdf

Tsukui, I. (2017). Jichitai to kigyō to no hōkatsu renkei kyōtei no kanōsei (Prospects of comprehensive partnership agreements between local governments and businesses). Nihon Keiei Rinri Gakkaishi, 24, 149-164.

Wrigley, N., Coe, N. M., \& Currah, A. (2005). Globalizing retail: conceptualizing the distribution-based transnational corporation (TNC). Progress in Human Geography, 29(4), 437-457.

Yahagi, T. (1994). Konbiniensu Sutoa Shisutemu no Kakushinsei (Innovativeness of the CVS system). Nihon Keizai Shinbunsha.

Yui, Y., Kubo, T., \& Miyazawa, H. (2017). Shrinking and super-aging suburbs in Japanese metropolis. Sociology Study, 7(4), 195-204.

Publisher's Note Springer Nature remains neutral with regard to jurisdictional claims in published maps and institutional affiliations. 